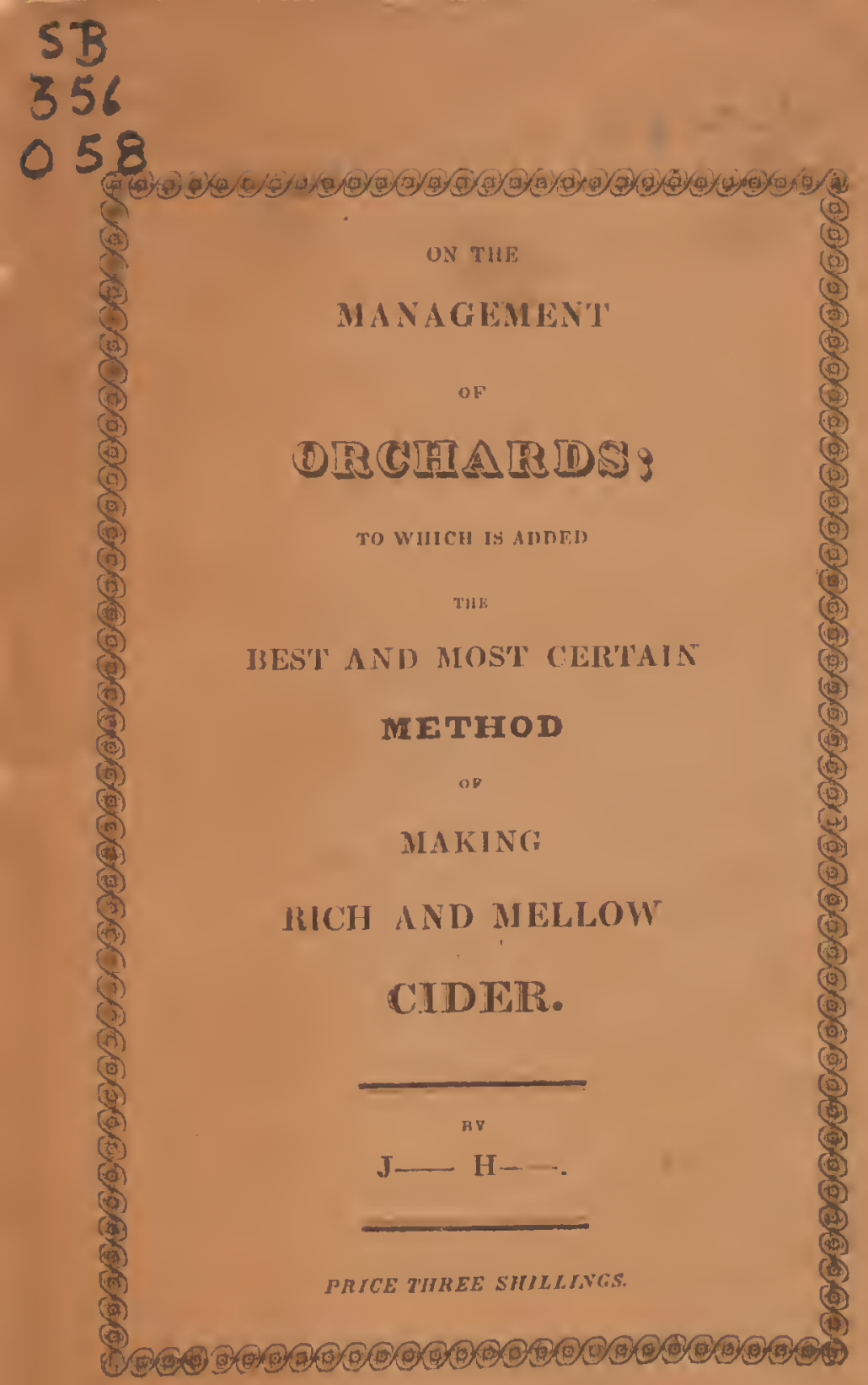




\section{F. J. CHITTENDEN}

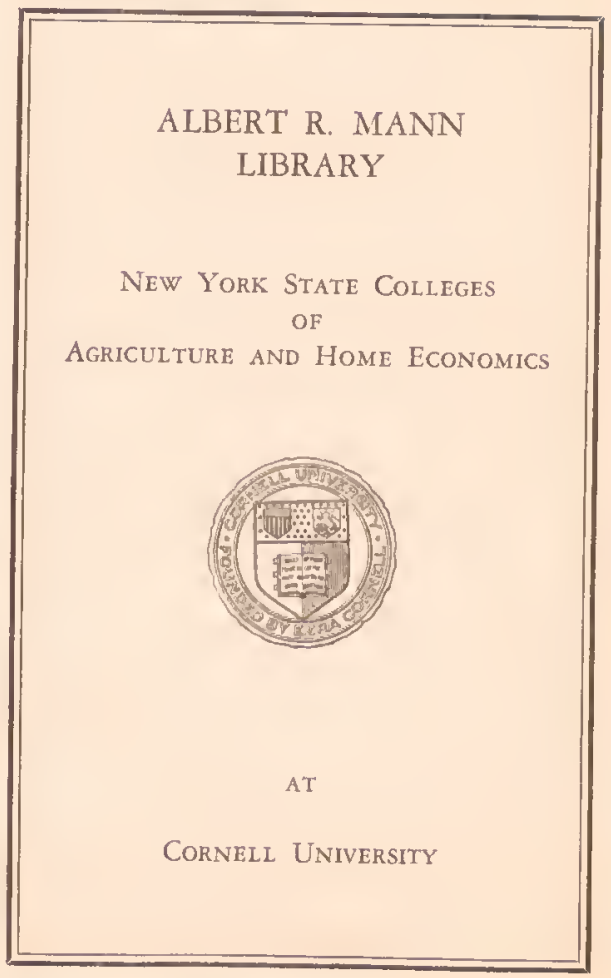




\section{DATE DUE}

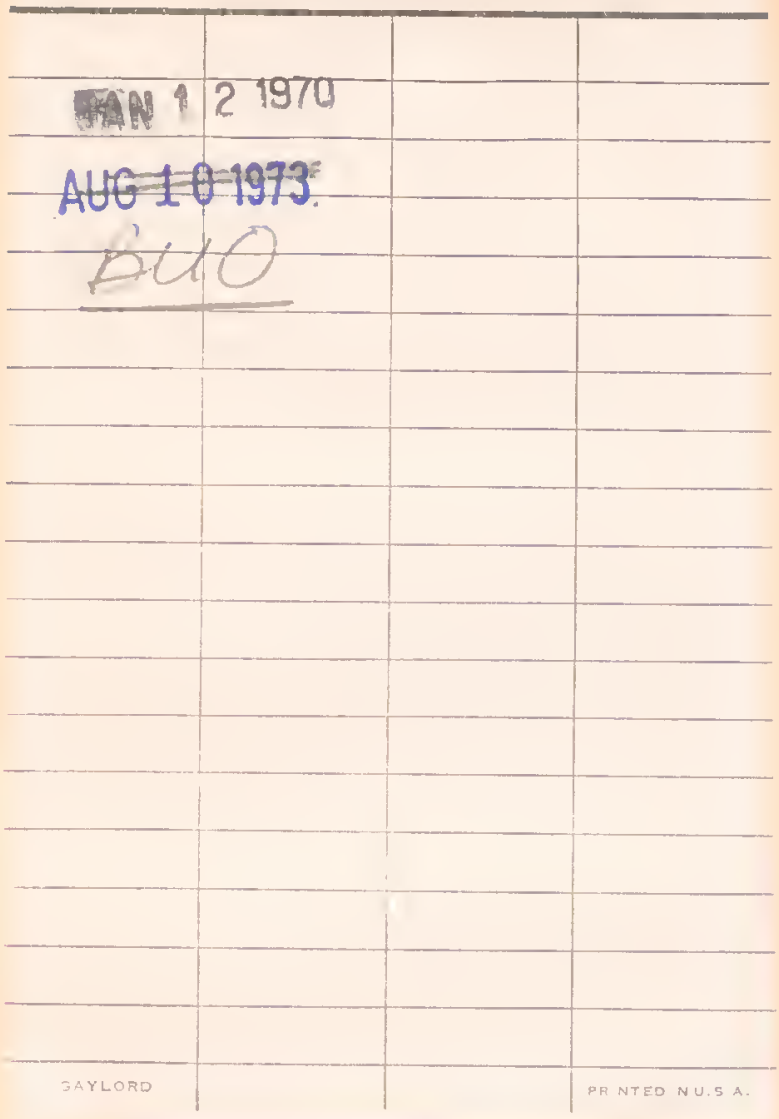





ON THB

\section{MANAGEMENT OF ORCHARDS,}

AXD ON THE

BEST METHOD of MAKING CIDER, Ec. Ec. 



\section{Management of Orchards,}

AND ON THR

\section{BEST METHOD OF MAKING

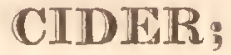

TOGETHER WITH THE

Necessary Instructions for its After Care,

SO AS TO INSURE IT

GOOD AND MELLOW.

aramonam

DEDICATED TO THE OWNERS AND OCCUPIERS OF ORCHARDS IN DEVONSHIRE,

B $\mathbf{Y}$

$\mathbf{J}-\mathbf{H}$

noworenen

Omnium rerum ex quibus aliquid acquirilur, nihil est 1gricullurâ melius, nihil uberius, nihil dulcius, nibil homine libero dignius.

Cickno, dz Orfic. 1, c. 42.

EXET ER:

PRINTED BY TREWMAN AND CO. HIGH.STREET.

1824. 


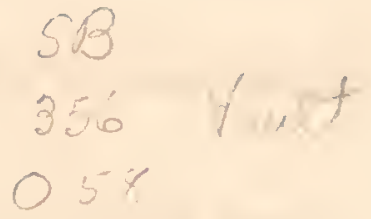

374584

Entered at Stationers' Hall. 
"LO! thoughlful of liyg gain, " Not of my own, I all the livelong Day

"Consume in medilation deep, recluse

"From Iluman converse; nor at shut of Eve

"Enjoy repose; but oft at Midnight lamp

"Ply my brain-racking studies, if by chance

"Thee I may counsel right; and of this care

"Disturbs me slumbering. W"ill thou, then, repine

"To labor for thyself; and rather chuse

"To lie supine'y; hoping Heaven will uless

"Thy slighted Fruils, and give thee Brend unearu"d?"

"Wouldst thou thy fals with gen rous Juce should frolh?

"Respect thy Orchards: Think not that the Trees

" Spontaneous will produce an wholesome draught."

"And slall we doubl

" $T$ " improve oul vegctable weallh? or let

"The Soil lie idir, which, wilh fit Manure

"Will largest Lsury repay, alone

"Empovired to supp'y what wialure asks

"Trugal, or what nicc. Apletile requires." 
ON THE

\title{
MANAGEMENT OF ORCHARDS,
}

\author{
\&ic. \& c.
}

As the purport of the following Tract is to convey information, tending to promote an increase of Profits to the Agriculturist, in that branch of rural economy, at present, either, not well understood, or, too much neglected, because the Climate aftords liberal returns without much Labor, it becomes quite unnecessary to offer apoJogy for its publication; particularly, as those who read attentively, will immediately discover, how, by attentive and judicious management, they may insure to 


\section{8}

themselves a high degree of pleasure and satisfaetion, at the same time that they derive a considerable peeuniary advantage.

The eultivation of the Vine in France, was greatly improved, and the art of making Wines, Brandy, and Vinegars, put upon a regular system of benefieial produet, by the united efiorts of CIIAPTAL, Rozier, Parmentuer, and Dussieus, men of the highest seientifie intelligenee, and Members of the Soeieties established for the improvement of Scienees and Agriculture in France.

When it is considered how great the benefits have been, that have resulted from their cxertions to establish a System that all might understand and practice, and how very similar our Orehard produetions are to the Vineyards of France, it beeomes a wonder, that some simple publication has 
not been addressed to our Cider Growers, partieularly in the enlightened County of Devon, developing a more regular, syste. matic, and consequently beneficial Plau of Management, than that too generally followed.

On almost every Farm in Devonshire, there is a sufficiency of Orchards to produce in what are rulgarly culled "Good bearing Iears," cnough Cider to pay more than the Rent of the whole Farm, although their extent shall not exeecd from onethirtieth to one-tenth of its measurement.

This "Good bearing Year" is looked for about onee in Thluree Years, and is regularly waited for by the Farmer as a matter of eourse,-he, taking few, if any, steps beyond a very moderate Dressing, in quantity far less than he would apply to a 
Meadow usually mowed for Hay, and leaving the Crop of Apples to the chanee of a "Lueky Year."

Should a Farmer (there are many, no doubt, besides Pinsent, of Chudleigh, and the MaYs', of Dunsford,) by better management than common, liave Apples in his Orchards every Season,- sueh Orehards are denominated, by the unthinking, "Lucky!" and little or no observation would be made on lis superior Knowledge, or the superior Method of Cultivation he practised.-No! " Lucky," is the term preferred by self love, as that passes no strietures on the observer's mis-management! Indecd, it would occasion no surprise, if, rather than be guilty of such a libel on limself, he were to attribute Pinsents saceess to the protection and visits of Mr. CoLERIDGE's friends, "The Pixies of Chudleigh Rock." 


\section{1}

It is not intended, in this little Traet, to oecasion any individual to feel personal offence; and, although some prejudices may be rather hardly touehed upon, it must be kept in mind, this is merely with a view to their eradication, that a better feeling, the result of knowledge and understanding, inay be substituted.

In matters not well understood, much mis-information, and a far grcater portion of mis-coneeption, are sure to prevail. As, for example,-It is a generally circulated opinion, "that frequent rackings make sweet Cider,"-henee, it is no uneommon affair for a Devonshire Farmer, on a wet day, to assemble all his People in his Cider Cellars, to rack his Cider; and this, from the false impression of its being essential to its mellowness, is so frequently repeated, that Color, Flavor, and Body, become considerably impaired. - On inspcction after 
this process, the Farmer finds some fow Hogsheads mellow, and to his wishes, many searcely so good as they were,-and the rest muel worse. In his surprise, he deelares " he eannot imagine how this can have happened, as all were equally well managed and racked at the same time."Henee, he eoneludes that racking is useless, and is indueed to negleet it altogether, as unneessary; - and even here, he finds some cause of eonfirmation of his views, as those Hogsheads that have been longest in getting into a state fit for raeking, when sold, being drawn of into clean Casks just at the time required, maintain a superiority, that to his mind, biassed in favor of that plan which brings least trouble with it, is eon. clusive.

One Farmer liears that another, (faned for sweet Cider, always rots his Apples, and, in consequenee, puts his Fruit in 
Heaps, and lets them remain 'till he is compelled to use a Scoop to load his Press with the disgusting mass; - and lie, too, expects mellow Cider !

Want of true knowledge,-want of system,-is all we liave to complain of; and this once made known, will be sure of being hept alive by interest and competition, to the benefit of the Growers and the Consumers of Cider.

Every Vegetable has a Pabulum or Foon peculiarly adapted to its licalthy growth; and, as this naturally abounds or is furnished by art,-or, on the other liand, is either absent or neglected,-so does a soil become congenial to what is grown in it, or otherwise.

The Earth is the stomach of Vegetables, and the fibrous Roots are their absorbent 
Vessels. As these Vessels are largely and healthily formed, to take up their Food,-or are defieient; - and, as that Food abounds or is wanting, - so is the Plant or Tree more or less healthy, flourishing in luxurianee of growth, or perishing by degrees-the vietim of discase and parasitic plunder!

How often is it to be observed, that Apple Trees throw forth a fine luxuriant Blossom, which, througl the kindness of Nature, appears, as it were, during a long period, to stand still as to growth or deeay,thus, giving time to the fibrous Roots to push their Months in the Earth in seareh of the requisite Nourishment to perfeet the Fruit. But, alas! it is not to be found,and those Blossoms, whose growth would rapidly have proeeeded to the formation of a Crop of Fruit, had Man done his duty, fall off abortive,-form small unwholesome 
Apples,-or become the Nidus for the deposit of the Egg of a Fly, whose thus continued race will commence fresh depredations the ensuing year, to the disgrace and disappointment of unthinking Man.

By long practice, all Farmers are aware how to prepare their Lands for Wheat, Barley, Oats, Peas, Beans, Turnips, \&c. and when they fail of obtaining a Crop, are at no loss, however they may try to qualify the fact to their Landlords and Neighbours, to account truly to themselves for the cause of such failure.

Why should not the Culture of Orehards be brought under as eertain a Management as Corn, or any other Vegetable produetion?

It is not meant, here, to be asserted, that a greater degree of difficulty will not be experienced than in the Management of 
Corn! But, then, the increased difficulty will be merely in proportion to the alsence of knowledge; and, as pains are taken to cultivate information, so will the obstructions to suecess disappear.

How many times do we notice tirat a piece of Wheat, which carries all the appearance of good managenent through the Winter, falls away in Substance and Color in the growing months of the Epring,-.. while other, that appeared thin and searcely worth letting remain, grows away to an abundant Crop! This is owing to the Plant, at that Scason of the Year, throwing ont its Fibres in search of Nourishment to perfect its Seed Stem, (for Noisture, Light, and Air, will alone produce the grassy matter of a Plant;) and, in proportion as the neeessary Pabulum and good Husbandry have been applied,-or, on the 
other hand, neglected,-so is the Crop ample or defieient.

Who has not seen this frequently in Orchards? - Who has not frequently observed, as has been remarked before, Trees covered with Blussoms and Leaves-neither of which have had support enough from their Roots to come to perfeetion?-It is not the "Lucky Year!" That is, the whole is left to Nature, and she had not lad time to eoncoct in the Earth a snficiency of matter for the production of a Crop.-. Vill not, however, the thinking mind be convineed, that had the proper Pabulum and Aitention been bestowed, the Crop (the Season being fitrorable,) would have resulted? For, let it be well understosd, that all Vegetables, before the Blossoms ean burst forth, send out their fibrous Roots to take up the Food neeessary for perfecting the Seed; and while the Blossom 


\section{8}

stands stagnated, they are pushing their subtle Mouths through the Earth in scarch of the required Nourishment;-wherc this is plentifully provided, in a Soil kept light and mellow around the Roots of the Trees, the difficulty is not low to obtain a Crop,-but would be found, if Experiment were madc, how to prevent olle! This is instanced in some Orchards, which are under highly superior Culturc, where Frosts have cut off the promised Fruit, by the'Trees bursting out into second Blossom on the same Year; and that this is the Truth, is a natter of easy inquiry, by Experinent among the minor Vegctables, such as Turnips, whose quick growth gives time for the observation, and whose disposition to form their Seed, when once excited, cannot bc stopped by cutting off the Sced Stem, however frequently repeated. 
By the way of illustrating what has been remarked of each Vegetable requiring a peculiar Food of its own, it is here worthy of observation, that although a Crop of Wheat, (generally speaking, cannot be successfully grown after a Crop of Wheat, without dressing,-still, a Crop of Barley, of the most saleable Color, can! This is owing to the Wheat never taking up what forms the peculiar Nourishment of Barley: Wheat requiring Gluten and Phosphate of Lime,-and the Barley, Nitrate of Potassa, all of which are contained in Animal Manure and Urine.

Some Farmers, being made aware of the different Pabula required by Vegetables, and of their not interfering with each other's growth, have, very beneficially, cultivated their Horse-Corn for their own consumption, to a unuch larger production, by sowing Oats, Barley, and Peas, together in the 
same Field,-reaping, of this "Omnium," frequently upwards of Eighty Bushels per Acre, where neither, separately, would have furnished Fifty.

Although it is gencrally admitted that Wheat cannot be grown after Wheat with any prospect of beneficial result, yet, it is certain, if the matter abstracted from the Land by a Crop of Wheat, could be restored, Wheat might be agrain successfully cultivated to the end of time in aunual succession,-and, in all probability, should this desideratum in Agriculture be ever ascertaincd, in Quantities per Acre, of which, at present, we have little or no idea.

Every Farmer, in the Vicinity of Excter, is aware that the quickest growth of Turnips is promoted by the use of the Scavenger's Dung, composed of Ashes of various sorts, and the Sweepings of the Strects;-the 


\section{1}

cause of this is easily attainable: Turnips abound in what Chcmists term lydroguretted Sulplutet, and this mattcr is contained in the Scavcnger's Dung, in a higher degree than in any other Manure that can be casily obtained.

These Remarks on Grain, Sc. may be considcred as somewhat foreign to the object of this Tract; thcy are, howercr, introduced, by way of lcading the mind through a subject so fully understood by Farmers, is the Cultivation of Corn, \&c. to a conviction of how gricat has bcen the general neglcet,-and how much may bc ac:complisted by judicious Managcment of Orchards and thcir produce.

Somcliow or other, notwithstanding the immense production of Orchards, thcir Produce claims the least attention of the Farmer in general; - that is, as relates to 
any really assisting management or helping hand! 'Thus, though Fifteen Seams of Hay per Acre would be a very large Crop to enlculate upon from his best Meadow Land,- - and Ten Hogsheads of Cider per Acre a common produce in good Orehards in "Fortunate Years," besides the undergrowth of Grass,- -he gives lis Meadows nearly Two Hundred Seams of Dung per Acre every Threc Years, and imagines the Shcep, with whom lie feeds off the Grass, and perhaps to whom he hauls a few Turnips in the Winter, to leave sufficient Manure for the renewal of the Pasture and the growth of Apples,-unless, indeed, he wants a Crop of Potatoes, and has no better place than his Orehards to grow them,-in which ease, he puts no more Dung for them than he would in any Field, and calls it dressing his Orchards! In his preparation, too, for Potatoes, he ploughs, instead of digging with a skilful hand, and 
thus promiscuously tears away the Root and Fibres of the Trees, which may not inaptly be compared to mutilating the Mouth of an Animal that is put up to fatten,- a proposal to do which, the most ignorant Pcrson on Earth would naturally term madness and folly.

Ploughing, and under-cropping Orchards, can be considered in no other light than a paltry systcm (arising out of ignoranee of the mischicf cffected,) of digging at the least Expence, and obtaining a Payment for the Labor and Manurc from an underCrop, instcad of generously awaiting for the Trees to make a return for them, and which they would do, by amply overloading the groaning Vcssels with rieh, stout, mellow Wine, under the following Management:-

Let the Orehards be manured every Year, directly aifter the Fruit is got in and the 
Grass fed off, with from One to 'Two Hundred Seams of Dung mixed with a Quarter or Half a 'Ton of Salt Ashes per Acre.

Let the Roots be dug round every Spring, so as to give fresh room to the Fibres, and to admit the Air, which is requisite to assist the decomposition of decaying Aninal and Vegetable Matter in the Earth, and which, until in a state of solution, (dissolved,) cannot be absorbed by the fibrous Roots.

Let the Branches be pruned Annually, by a proper and skilful Person, so that bearing Wood may always be left in suffi-

a. A Braneb supposed to bave done bearing, and which is to be ent ont at $b$. This is to be succeeded by $c_{9}-$ which. when also done with, is to be remored at $d_{2}-$ e then takes its place, and when wanted to be praned, is to be taken off at $f$, leaving $g$ to succeed. 


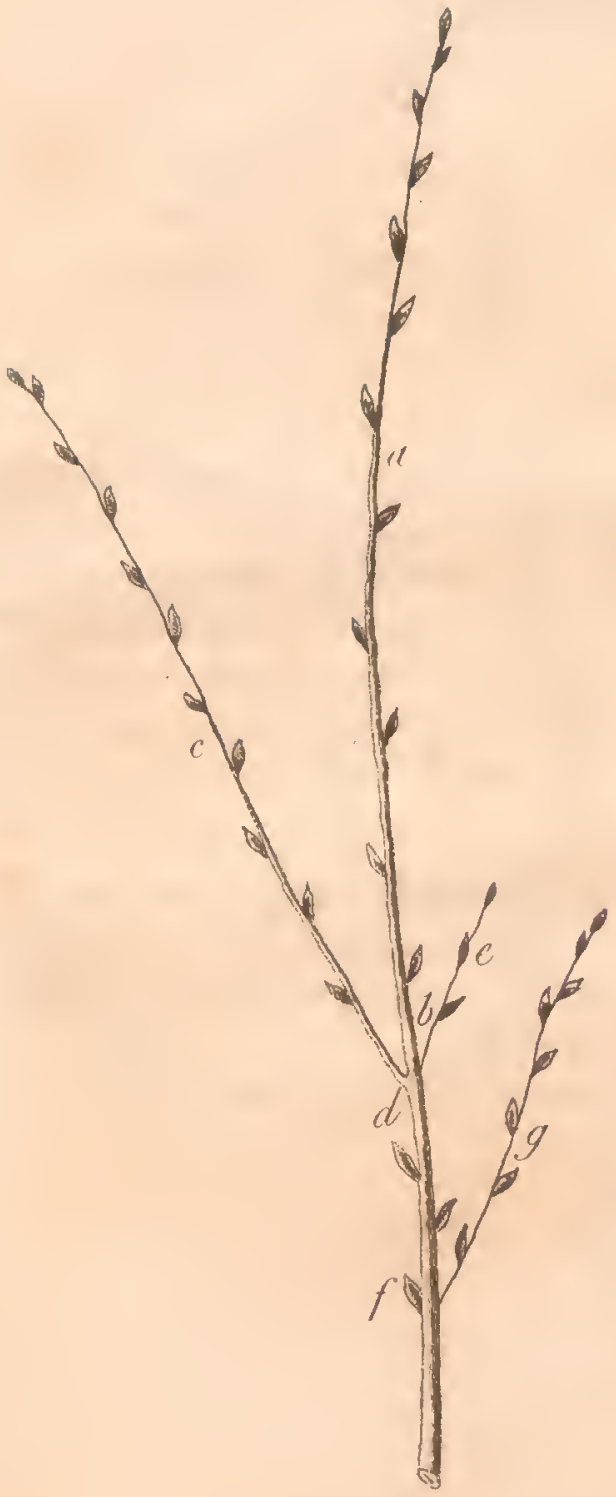




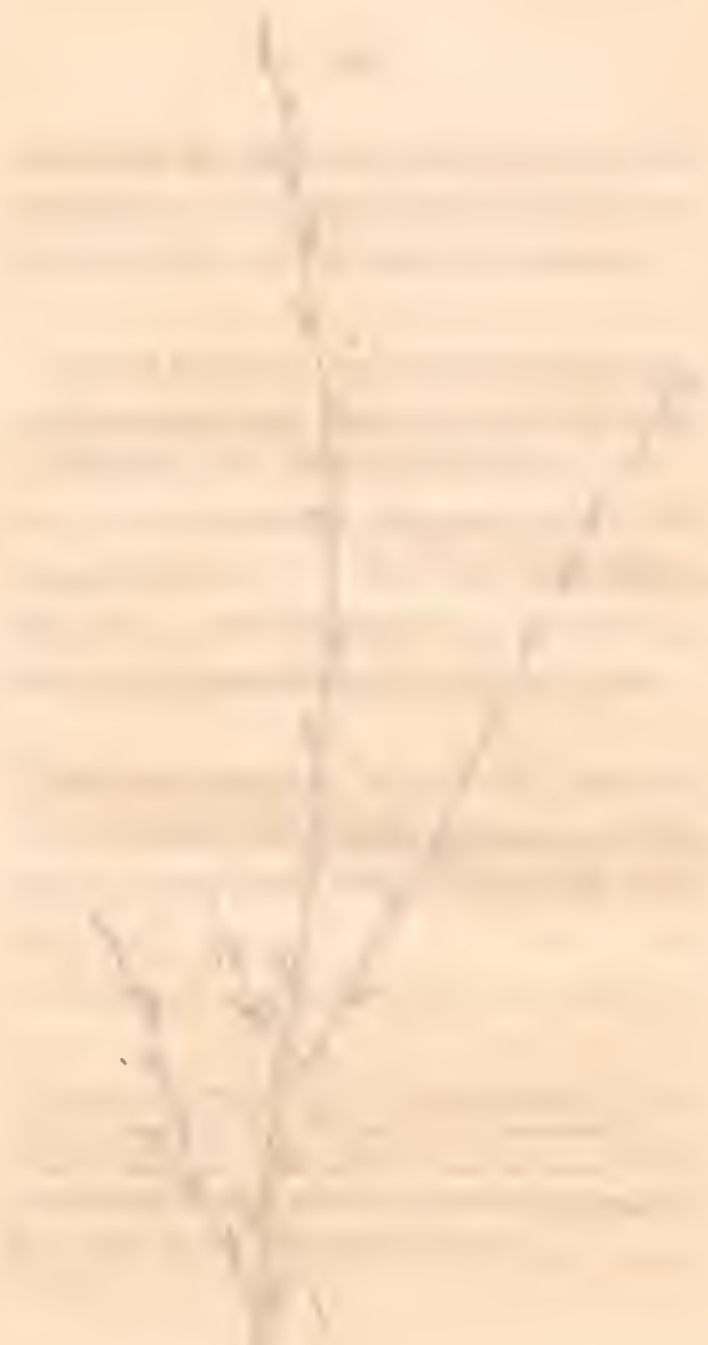




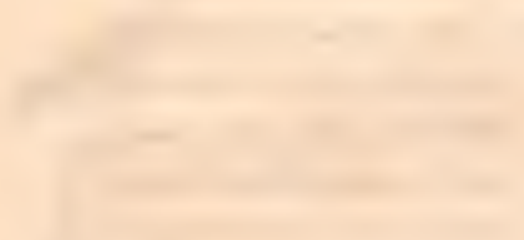




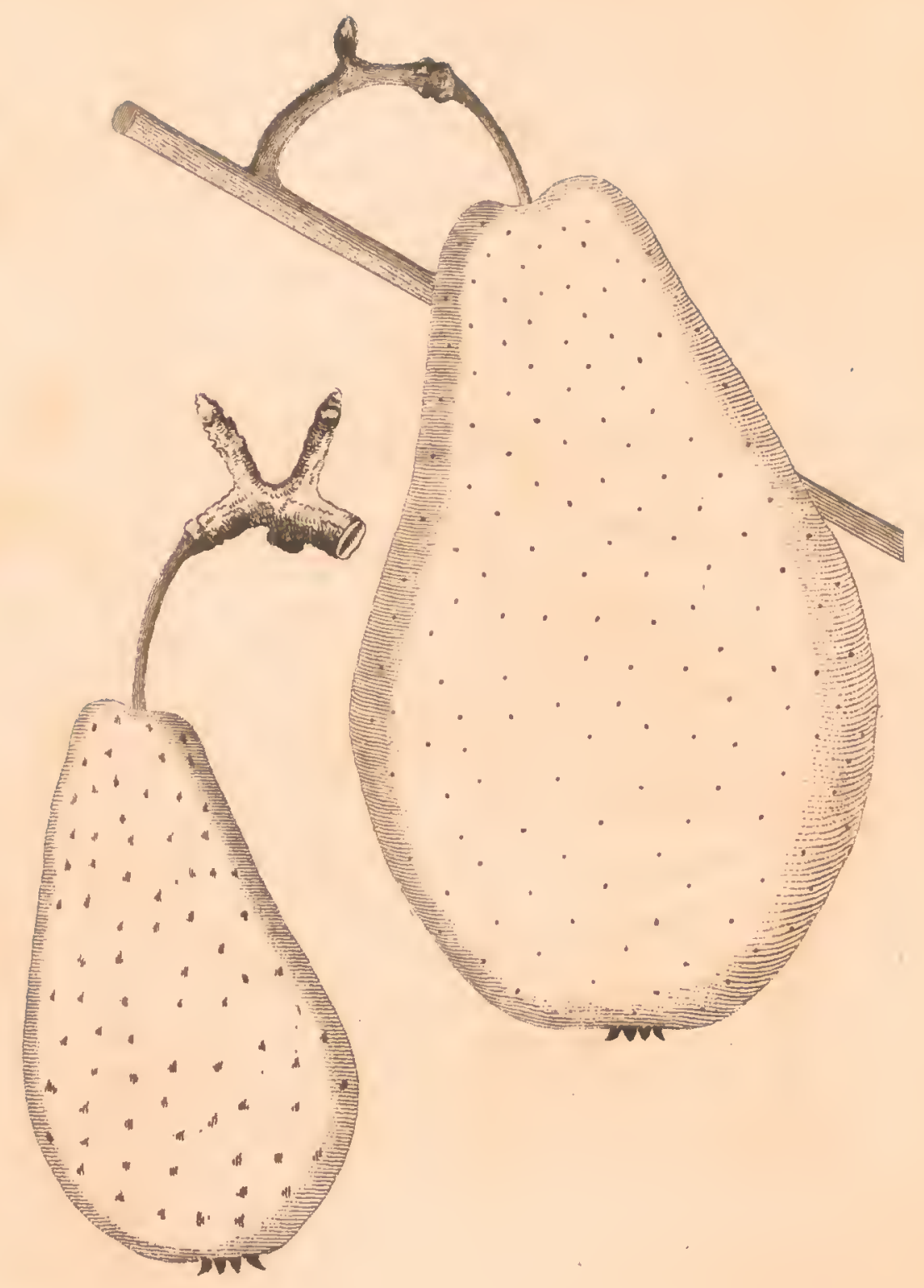


cient Quantity, and a due succession of Shoots insured; (the best time is in April or May, at the same time taking care to remove all dead and superabundant Branches, and to carefully cut out the cankered Parts; this will, at the same time that it efficiently admits the Light and Air, prevent the absorption of Sap by unproductive Parts, and leave the juicy circulation more abundant for the perfection of a Crop of full, noblesized Fruit, fur exceeding any produced even in the luckiest of "Lucky Years."

As a specimen of what is effected for Fruit by judicious Pruning, a Sketch of Two Pears, grown on the same Tree, the same Season, is here exhibited,-the small one was grown on a Branch pruned with Spurs, according to the old System, - and the other fine Specimen resulted from the Branch itself, on which no Spur was suffered. 
'To keep the Bark of the Trees clean, and free from Inscets, the following Wash should be used, as recommended by Mr. Forsytu:-Take

Fresh Cow Dung, a little Lime, and

$$
\text { Wood Ashes, - }
$$

Mix these with Urine and Soapsuds,

$$
\text { for use. }
$$

Wash the Trees with this Mixture, made about the consistence of Plasterer's White Wash, and lay it on in the same manner, in the Months of February and March; and, in the course of the following Summer, a fine new Bark will be observed.-If this be again repeated in the Autumn, it will destroy the Eggs deposited by various Insects, and further improve the Bark.

The same Mixture, made thicker, should be put over those Parts from whence the cankered Wood or supcrabundant 
Branches are removed. as it will be found to heal the Wyound, and renew the Bark.

Let not the Farmer think this useless trouble, but rather turn his mind to a full belief in a beneficial result, which will enable him to look forward to meeting with pleasure the demands of his Landlord.

Having shewn how to produce good Crops of exeellent Fruit,-it now becomes necessary to advise as to the best Method of making the Apples into rich, stout, mellow Winc,-and which may be effected by a striet observance of the following Rules:-

Let the Fruit be seleeted,-ripe and perfect, and laid together in Heaps, not more than Eighteen Inelies deep, till mellow,not rotten!

In this mellow state let the Apples be ground. c 3 
Hair-Cloth is better than Reed for wrapping round the ground Pomace, when placed in the Press, -as not being so subject to the attacks of parasitic Fungi, the Pollen from which we vulgarly call "Mold," or " Must."

Let all the Utensils and Casks be perfectly dry, sweet, and clean.

Put the Juice, as it comes from the Press, into large open Tubs, and let it remain therein till the Head rises, which skim carefully off; -and then put the Cider into Casks, observing not to fill them unore than Three-Fourths full.-Dissolve One Ounce of the best Isinglass in some Cider, and mix it with that in each IIogshead, stirring it well up.-Bung the Casks close, and let a Spile be put in the Head of each, and a little of the Liquor drawn therefrom daily into a clean thin Wine 
Glass, that it may be known when the Cider is bright, which, as soon as it is observed to be, let it be rneked,- -and not before; unless, indeed, it should, from atmospherie or other eauses, get into a state of fermentation,-in which case it should be instantly raeked, and the racking eontinued till the fermentation eeases.

For, let it be remembered always, that, in proportion as the vinous fermentation is earried on, the Spirit is elieited, and the Sweetuess subsides into the new produet of Wine. It is of the greatest importance, therefore, that the vinous fermentation does not proeecl beyond its due limits;-and, that it may be stopped at the proper time, it is neeessary to wateh the Must, or newmade Cider, by Day and Night, through the whole of the period,-because, soon after the termination of the vinous fermen- 
tation, the acetous fermentation, or formation of Vinegar begins. But, from a variety of eauses, it may happen that the vinous fermentation will go on too slowly,-very much to the deterioration of the Cider; in such eases, it will be advantageous to remove the fermenting Liquor to a warmer Cellar, where the temperature of the Air may be raised to 55 Degrees of FAHRENHur's's Thermometer, if so great a degree of Heat be wanted. An increase of lieat always promotes and aceelerates the vinous fermentation, and much vigilance is required, at such times, to regulate the fermcutation so exeited, fur fear of converting the Cider into Vinegar.-'ithe first symptoms of which have been frequently observed within a few Hours after the close of the vinous Process thus artificially excited. As IIeat promotes, so, on the eontrary, Cold will restrain the aetivity of fermentation,-and, on the skill and address with 


\section{1}

which these $\Lambda$ gents are applied, the Pcrfcction and Prcservation of the Cider will dcpend.

The best Cider is always produced when the vinous fermentation has been fully completed. 'This may be known by the Bubbles ccasing to rise, and to increase the Hcad or Scum, which has been gradually formed on the Surfacc of the Liquor, and this critical moment for the first racking, should never be lost.

If the fermentation be carried on in Casks instead of open Vessels, greater vigilancc must be used, because what is going on is out of sight,-and carc musi be taken that the Cidcr bc racked the very moment the slightest degrce of hissing is perceptible; - and, as Acids arc formed by the absorption of that part of thc atmospheric $\dot{A}$ ir which is the acidifying principle, by 
Chcmists termed Oxygen, it is cxpedient that the Cider be kept as much as possible from its influence, and thereforc it lias been recommended in the process of racking, to use a small Cock, that affords only a thin quiet Strcam, and that the Vessel into which the Liquor runs should be as near the Stream as possible,-because, in employing a large Cock, the Cider rushes out with so much violence, as to iucorporate a vast Quantity of Air, which, couscqueutly, aids its progress in becoming Vinegar. There is litfle more to add on these matters, except to rccommend a Straw Mat as a covering for the Tubs, when Tubs are used to receive the Must, during the period of the viuous fermentation, - and to statc, by way of example of the caution required in racking,-that at Dijon, in the management of that delicate Wine Burgundy, the Freuch Factors contrive to rack their Wincs without exposing them to the Air 


\section{3}

at all! This may be easily cffected, by the Casks to be racked being placed on a ligh Stilling, so that the receiving Cask may stand under the Cock of the other,- to the Cock should be fastened a small Hose, long enough to reach from it to the Bottom of the Cask into which the Cider is to be racked, and into which, by these means, it will run with perfect facility and quietude. When the Cask that is racked from requires stooping, the Hose may be removed, and the remains of the Cider drawn off into Cans, previous to its transit iuto that already drawn of:;-this is particularly necessary, as constant examiuation of the Liquor, at this period of the racking, is especially required, to prevent any of the Lces, or Dregs, being mixed with the bright Cider. A Siphon should never be used for the purpose of racking, as it is almost invariably sure to produce Foulness in the Liquor to be racked, by the agitation unavoidable in introducing it into the Cask. 


\section{4}

That the necessity of racking, the moment the Lees, or Dregs, are deposited, may be fully understood and appreeiated, it is proper to olsserve, that as soon as this takes place, they assume a Flavor of their own, proportionably vicious and bad tasted, instanced in the tartaric deposition of Port Wine, as the Liquor becomes mellow and bright; and should these Lees, in Cider, be suffered to mix agrain with the brirhth Liquor, it will become so affected as never to be perfectly recoverable;-henee, in racking, not the sinallest Quantity of that which is not bright should be allowed to pass into the Cask with that which is, or the racking must be repeated,-a eircumstanec always to be aroided, if possible, as being destruetive of Color, Flavor, and Body.-So far is it untrue that frequent raekings make mellow Cider.

To effect a porfect Brightness, use the Isinglass as before directed, - and let it be 
repeated, if necessary, remembering always to rack off within Four or Five Days after fining; then bung the Casks close, and let them be placed in a Cellar of even temperature, not exceeding 48 Degrees of Fahrenieit's Thermometer, where the Cider may remain for use to any age.

By such treatment, Cider will retain its genuine relish, and be elassed, as it deserves, under the denomination of Wine, possessing Strength that will heep for Years, - that will invigorate the Farmer and his People during the toils of labor,-and eheer the hearts of limself and Friends to lindly merriment in the hours of relaxation.

As bad Seasons, however, will oceur, and frequently, in spite of every eare, the Farmer will be compelled to use a mixture of different Fruit, in various stages of ripen- 
ing, to compose the Pomacc,-thc Cider resulting therefrom will be of inferior Quality, and be found cloudy and turbid, -and ill-disposcd, under every care, to assume the requisite brightness. Frequent observations of this Liquor will be necessary,-and, although the poverty of the Cidcr, under such circumstances, can ill bear the exhaustion of trequent rackings, yet its disposition to ferment may be so constant, that necessity will enforce the repetition of racking,-and no better course can be adopted. In this desperatc case, much advantage will be derived from the observance of the Rules and Management lierein laid down,- as many Improvements in the Treatment of Orchards, the Fruit, Pomace, and the Must, have been suggested,- and, consequently, a more generous Liquor will be obtained, than can be had (unless by chance,) amidst the mistakes and errors of the present usage. 


\section{7}

Not haring resided long enough in the County of Devon to become acquainted with the different Apples that are cultivated, -and having noticed the same Fruits to have different names in different districts, I shall not attempt to describe or enumerate the various sorts, but recommend the Farmers to be eareful in observing the Orchards in their respective neighbourhoods, and to select for their own, those Apple Trees, which experience has shewn to be best suited to their particular situation and soil.

It is hoped, the foregoing Observations, which are purposely condensed to make them more generally useful, may prove aeceptable to those who possess Orchards, -and the observance of the System laid 
down, be the means of produeing mueh Satisfaction and Profit,-and of speedily annihilating the Expression, as well as the Liquor, which is now too frequently met with-

"Good Working-Man’s Cider!"

$$
\text { J. } \boldsymbol{H} \text {. }
$$


- 
. 

